he would when called to the victim of a traffic accident at home. Kneeling up on the middle bench of the lurching Landrover and bending over Anthony's head, he began to examine the face, eyes and neck. Paul Kimjinge in the back similarly undid Anthony's clothing, helped by Isaiah. He tested limbs, chest and abdomen. There was a good deal of bruising on the body, the clothes were in shreds, but everything above the neck had come off much the worst. Philip prised the eyelids apart gently and found the right eye intact. In the bloody crushed mess on the left he was sickened to see a small delicate fold of dark green directly under his examining finger: the eye had been stabbed, and that was a curtain of iris prolapsing through the wound. The clear stuff oozing there was fluid from the eyeball. Anthony was unconscious, taking slow, deep breaths.

The two doctors compared notes. Paul said "He's been badly knocked about but he's basically OK from the neck downwards. May have some rib fractures. How about your end?"

"Basal skull fracture, deeply unconscious, could be suffering further brain damage from bleeding inside the head right now. His left eyeball is cut, he probably won't see again with it. If he survives."

They reached the town on the main highway and turned. Inivoru asked "Do we stop?" and Paul said "No, straight on." The road surface became broken, and Anthony's frail body bounced up and down as the car weaved around potholes. Paul Kimjinge spoke to the others.

"Let's have our story straight. We've been to Agimbo Hospital, where they had this bad accident in. We don't know how it happened, but offered to take him back with us to Brulu because he needs skilled help, surgery. That's all we know."
The guards at the checkpoint were bored. They saw the human mess in the back, exchanged a few words and waved them through. The Landrover rattled on, the floor beneath Anthony's head stained by dripping blood.

"What happened?" Philip asked on the last leg to Brulu, when they had done all they could for the wounded boy. Paul Kimjinge shook his head in rage and sorrow:

"Don't ask. Anthony is one of my link men with the resistance in the mountains. The large village he was visiting has just been cleaned up by the People's Revolutionary Force. Someone must have told them he was coming. The People's Revolutionary Force set on him, stuck a knife in his eye for good measure, and left him to the villagers as an example. Loyal men brought him out later, and you've seen the rest. Do you think he'll live?"

Philip did not know. They had no difficulty with the roadblock into Brulu either, and drove straight to the hospital. Anthony remained unconscious for two days. Then he recovered, blind in one eye.

Blow the Wind Southerly by Professor Thomas Sherwood, from which these extracts are taken, may be obtained free of charge from Southerly, 28 Sopwell Lane, St Albans, Herts ALl 1RR. Donations are invited, however, to Intermediate Technology, a charity concerned with self help for the Third World.

\section{Cambridge CB5 8SU}

THOMAS SHERWOOD, FRCP, FRCR, dean, University of Cambridge School of Clinical Medicine

Correspondence to: 36 Church Street, Fen Ditton, Cambridge CB5 8 SU.

\title{
Death by degrees
}

\section{ANDREW ROBINSON}

\section{Introduction}

There is sufficient good advice available to graduates in medicine for young doctors to be very well informed about many matters affecting their choice of career..$^{1}$ Assuming, however, that our young doctor is progressing in his choice of career to the satisfaction of himself and others, it is much harder for him to obtain information pertaining to his own longevity. It is, of course, possible to reduce personal risk factors, particularly in relation to smoking, ${ }^{2}$ and, though alcoholic doctors have a gloomy prognosis, ${ }^{3}$ alcohol in moderation may not only enhance enjoyment of life but also marginally prolong life. ${ }^{4}$

This study was designed to give some further career guidance to any young doctor wishing for a longer life.

\section{Method}

The General Medical Council (GMC) register of the names of all medical practitioners erased after confirmation of death was examined for 1986 . The sex, year of initial graduation, year of graduation for a higher degree (where applicable), and qualifications were noted, but, as the precise age at death was not known and there was no information on specialty, obituaries from the British Medical foumal (BMF) for 1986 were used to supplement the information from the register.

I assumed that initial graduation occurred at the age of 23 (the midpoint for the quinquennium 21-25 years), and the frequency distribution of age at death was tabulated on quinquennial midpoints up to the age of 103 . Thus age at death for GMC erasures was calculated as the difference between the year of death and year of initial graduation with the addition of 23 years.

In calculating the standard error of the difference between population or sample means log (105-age) was used to correct for the skewed distribution of deaths. As the populations from the GMC data were large a standard normal distribution was assumed when comparing means. The smaller $B M \mathcal{F}$ sample means were compared with $t$ tests.

To make a substantial correction for bias in survival advantage-that is, the advantage conferred by surviving long enough to obtain a higher degree- deaths before the quinquennium $36-40$ years were excluded. The period up to the third quartile between initial graduation and obtaining an MD was 9.6 years (median $5 \cdot 1$ years).

\section{Results}

The GMC register recorded 1056 deaths, of which 883 were men. Women medical practitioners had a significantly higher mean age at death than men-77 $v 71$ (multiples of the standard error of the difference (SED) in the difference between $\log$ means $=5 \cdot 88$; see table for $\log$ means, $95 \%$ confidence intervals, and SD when these are not quoted in the text). The mean age at death for those who had a doctorate (MD) was significantly higher than the mean age at death for those who had a diploma of membership or fellowship of the royal colleges (multiples of SED in the difference between log means = 6.87) or for those who had a bachelor's degree or licentiate qualification (multiples of SED in the difference between $\log$ means $=8 \cdot 6$ ). Of those who had an MD, $12.8 \%$ were women compared with $16.9 \%$ of the remainder.

The $B M \mathcal{F}$ published 446 obituaries, 395 of which were for men. The mean age at death of each gender sample did not differ from the appropriate GMC gender population mean (for men multiples of SED in the difference 
between the means $=1.51$; for women multiples of SED in the difference between the means $=1 \cdot 55$ ).

Categorisation of the three largest groups was based on the predominant type of practice during the doctor's professional lifetime. There were 171 general practitioners, 203 hospital doctors, and 42 community medicine specialists. There were no significant differences in the mean ages at death between these categories (between general practitioners and hospital doctors $\mathrm{SD}=0.187, t=1.317, \mathrm{df}=372$, NS; between general practitioners and community medicine specialists $\mathrm{SD}=0 \cdot 214, t=0 \cdot 359, \mathrm{df}=211, \mathrm{NS}$; and between hospital doctors and community medicine specialists $\mathrm{SD}=0 \cdot 133$, $t=1 \cdot 420, \mathrm{df}=243, \mathrm{NS}$ ).

Possession of a higher degree (MD, $\mathrm{PhD}$, or $\mathrm{DSc})$ was associated with a significantly higher mean age at death for general practitioners $(83$ for those with a higher degree $v 75$ for those without; SD $0 \cdot 225, t=2 \cdot 867, \mathrm{df}=167$,

Data on degrees and mean age of death of GMC population and doctors with $B M \mathcal{F}$ obituaries

\begin{tabular}{|c|c|c|c|}
\hline & $\begin{array}{c}\text { Mean age at } \\
\text { death (years) }\end{array}$ & Log mean & $\begin{array}{l}95 \% \text { Confidence interval } \\
\text { (SD) }\end{array}$ \\
\hline \multicolumn{4}{|c|}{$G M C$ register } \\
\hline Men & 71 & $3 \cdot 450$ & 3.420 to $3.480(0.409)$ \\
\hline Women & 77 & $3 \cdot 198$ & 3.158 to $3.238(0.534)$ \\
\hline MD holders & 86 & $2 \cdot 930$ & 2.831 to $3.028(0.562)$ \\
\hline Diploma holders & 75 & $3 \cdot 415$ & 3.318 to $3.512(0.710)$ \\
\hline Registration holders & $\begin{array}{c}76 \\
\text { BMf obituaries }\end{array}$ & $3 \cdot 399$ & 3.358 to $3.440(0.559)$ \\
\hline Men & 75 & 3.412 & 3.371 to $3.453(0.417)$ \\
\hline Women & 83 & 3.079 & 2.929 to $3.232(0.547)$ \\
\hline General practitioners & 76 & $3 \cdot 375$ & 3.301 to 3.449 \\
\hline Hospital doctors & 74 & 3.435 & 3.383 to 3.487 \\
\hline Community medicine specialists & 77 & $3 \cdot 347$ & 3.251 to 3.443 \\
\hline \multicolumn{4}{|l|}{ General practitioners: } \\
\hline With doctorate & 83 & 3.079 & 2.902 to 3.255 \\
\hline Without doctorate & 75 & 3.403 & 3.325 to 3.481 \\
\hline \multicolumn{4}{|l|}{ Community medicine specialists: } \\
\hline With doctorate & 83 & 3.073 & $2 \cdot 866$ to $3 \cdot 281$ \\
\hline Without doctorate & 74 & $3 \cdot 392$ & 3.291 to 3.494 \\
\hline \multicolumn{4}{|l|}{ Hospital doctors: } \\
\hline With doctorate & 76 & $3 \cdot 363$ & 3.272 to 3.453 \\
\hline Without doctorate & 73 & $3 \cdot 457$ & 3.397 to 3.517 \\
\hline
\end{tabular}

$\mathrm{p}<0.01)$ and for community medicine specialists $(83 v 74$ years; $\mathrm{SD}=0.084$, $t=2 \cdot 490, \mathrm{df}=40, \mathrm{p}<0.02)$. No significant difference, however, was found for hospital practitioners $(76 v 73$ years; $\mathrm{SD}=0 \cdot 131, t=1 \cdot 772, \mathrm{df}=198, \mathrm{NS})$.

\section{Discussion}

There are many factors that affect general susceptibility within a given occupation. ${ }^{5}$ For those contemplating a career in either general practice or community medicine, however, possession of a higher degree is associated with a longer life. Possession of a higher degree was rarer in these groups; while $36 \%$ of hospital doctors held a higher degree, only $12 \%$ of general practitioners and $14 \%$ of community medicine specialists held one. The enhanced self esteem as a rara avis may account for this difference.

Holders of a higher degree are also more likely to have an obituary published in the $B M F: 12 \%$ of doctors on the GMC list had an $M D$, while $24 \%$ of the deceased in the $B M \mathcal{F}$ had held a higher degree.

I am grateful to Professor N Kreitman and to Mr J Duffy for advice on preparing this paper.

\section{References}

1 Rhodes P. Letters to a young doctor. London: British Medical Association, 1983.

Enstrom JE. Trends in mortality among California physicians after giving up smoking: 1950-79. BrMed f 1983;286:1101-5.

Murray RM. Characteristics and prognosis of alcoholic doctors. Br Med $\mathcal{Y}$ 1976;ii: 1537-9.

4 Marmot MG. Alcohol and coronary heart disease. Int $f$ Epidemiol 1984;13:160-7.

5 Marmot MG, Shirley MJ, Rose G. Inequalities in death-specific explanations of a general pattern. Lancet 1984;i:1003-6.

\title{
A newly discovered class of allergens: textile dyes?
}

\author{
CAROLINE RICHMOND
}

I wrote the manifesto for the Dye Related Allergies Bureau (DRAB) (p 1596) as a spoof on the literature put out by those who wish to protect us from food additives, fluoridation of drinking water, and the like. Most of its statements are obviously or probably true; I assumed that any intelligent person would realise that many other obvious truths were omitted and that the untruths were patently absurd.

I wrote it after discovering that food additives are probably harmless, have been carefully screened, and are continually being monitored by government scientists world wide. I subsequently wrote a short defence of additives in New Scientist and was attacked for it, ferociously and without warning, by the food lobby. Shortly afterwards I described the events in the BMF's Medicine and the Media column (15 March 1986, p 754). A Mr Geoffrey Cannon wrote a vigorous reply, and a food messiah, who shall be nameless, sent the $B M F$ a detailed letter of petty criticism, written at gale force and marked "not for publication," which is a further example of the sort of behaviour I had complained about. I did have some favourable responses: two allergy specialists in the National Health Service wrote to me describing how some allergists and private allergy clinics, often aided by credulous or sensation seeking journalists, use food additives and similar scares to exploit gullible and depressed people.
This scenario is made worse by self help organisations of parents of energetic children or adults with psychosomatic (or sometimes frankly psychotic) symptoms. Many such people are keen to get a diagnosis of organic illness, and, having succeeded in doing so from a medically qualified fringe practitioner, they then proceed to spread the gospel that the ordinary annoyances to which flesh is heir-indigestion, thinning hair, poor appetite, indifferent concentration, dysmenorrhoea, and the rest-are allergic disorders.

The case against food additives includes a few grains of valid criticism but also reflects a long tradition of public fear of technologies inflicted on "us" by "them": milk pasteurisation and water fluoridation are two of many that are or have been preached against by the health food magazines. In recent years these messiahs have been joined by people from the loony left who use health as a route to attack industry and find foods and pharmaceuticals easy game.

After food additives, pasteurisation, infant feed formulas, and food irradiation, all of which have been annexed by the militants or the messiahs, what was left for the next budding evangelist? Why, textile dyes, of course. So I wrote the DRAB manifesto but realised that it was unsaleable as journalism. Experience has taught me that 